\title{
Article \\ Prevalence and Characteristics of Orthorectic Disorders in Adolescence and Young People: Polish Preliminary Studies
}

\author{
Natalia Kaźmierczak-Wojtaś ${ }^{1}$, Rafał Patryn ${ }^{2}$, Anna Zagaja ${ }^{2}$, Mariola Drozd ${ }^{2, * \mathbb{D}}$ and Antoni Niedzielski ${ }^{1}$ \\ 1 Department of Psychology, Medical University of Lublin, 20-059 Lublin, Poland; \\ nataliakazmierczakwojtas@umlub.pl (N.K.-W.); antoniniedzielski@umlub.pl (A.N.) \\ 2 Department of Humanities and Social Medicine, Medical University of Lublin, 20-059 Lublin, Poland; \\ rafalpatryn@umlub.pl (R.P.); annazagaja@umlub.pl (A.Z.) \\ * Correspondence: marioladrozd@umlub.pl; Tel.: +48-81-448-68-50
}

Citation: Kaźmierczak-Wojtaś, N.; Patryn, R.; Zagaja, A.; Drozd, M.;

Niedzielski, A. Prevalence and Characteristics of Orthorectic Disorders in Adolescence and Young People: Polish Preliminary Studies. Nutrients 2021, 13, 1568. https:// doi.org/10.3390/nu13051568

Academic Editor: Joanne Harrold

Received: 10 March 2021

Accepted: 5 May 2021

Published: 7 May 2021

Publisher's Note: MDPI stays neutral with regard to jurisdictional claims in published maps and institutional affiliations.

Copyright: (C) 2021 by the authors Licensee MDPI, Basel, Switzerland. This article is an open access article distributed under the terms and conditions of the Creative Commons Attribution (CC BY) license (https:// creativecommons.org/licenses/by/ $4.0 /)$.

\begin{abstract}
The aim of this work was to assess orthorectic behaviors among young people and to evaluate their attitudes towards caring for their health. The study was conducted in 2019 on a group of 538 respondents aged 16-35. After analysis, 65 questionnaires were eliminated from further research, and the assessment of orthorectic disorders was performed using a method based on the modified ORTO-15 questionnaire on a group of 473 respondents. A large percentage of them exhibited an increased risk of orthorectic behaviors (32.8), which was higher among women than men $(34.7 \%$ and $28.2 \%$, respectively). People with higher risks of orthorectic disorders significantly more often reduced their consumption of foods high in fats and sugars. Attitudes of people with orthorectic disorders towards health care proved neutral, with a tendency to be positive. Nutritional behaviors observed in the studied group show some irregularities, which indicates the need for preventive and educational measures aimed at increasing awareness of the role of proper nutrition among young people. The obtained results may be the basis for further research on ON symptoms. One of the major areas of future research would be to create a reliable diagnostic tool which would allow for distinguishing between orthorexia and overdiagnosis.
\end{abstract}

Keywords: risk of orthorectic behaviors; adolescent; young people; health

\section{Introduction}

Mental orthorexia (Orthorexia nervosa-ON, from Greek ortho-correct, proper; orexisappetite, hunger) is defined as a pathological fixation (obsession; care; preoccupation) on eating proper and healthy food. The obsession with healthy eating results from the desire to improve one's health and maintain their well-being.

The term was first introduced in 1997 by an American physician, Dr. Steven Bratman, who described it as a "fixation on eating healthy foods" [1]. It is worth noting that Bratman did not base the description of $\mathrm{ON}$ on empirical research, but on personal experience. In his book titled "Health Food Junkies", he presents his struggles with ON along with cases of other people whose strict diets led them to this disorder. In the book, he describes the symptoms that characterize this disorder, including an obsessive focus on the quality of consumed products and the ways in which meals are prepared [1]. Additional symptoms of the orthorectic disorder include thoroughly analyzing the source, production and packaging process of foods available on the market [2,3] and excluding foods considered unhealthy or impure [4-7]. People with orthorectic disorders often limit or completely eliminate specific food groups, such as meat, dairy products, grains, ready meals, non-seasonal products [1], genetically modified foods high in fat, salt or sugars, foods that contain pesticides and sensitizing substances [8]. It is also common practice to eat food derived exclusively from organic farming that does not contain artificial substances or preservatives [2,9]. For people with an ON disorder, food is primarily a source of health, not pleasure. The concept of "healthy" food is an individual matter and can change depending on a person's mood, 
beliefs or knowledge about food and nutrition. For this reason, it is difficult to clearly define what makes a given product perceived as "healthy".

The development of ON may be triggered by a doctor's/dietitian's recommendations regarding the use of a proper diet, the desire to overcome chronic diseases, negative life events and mental disorders. Risk factors can include the use of alternative diets (e.g., vegetarian, vegan, macrobiotic), nutritional restrictions or a desire to live in harmony with nature [1,2]. From a medical point of view, a direct effect of a selective approach to diet may cause nutrition deficiency, leading to malnutrition and weight loss [1,2,10-12]. In extreme cases, ON can have the same consequences as severe anorexia, i.e., osteopenia, anemia, hyponatremia, hypokalemia, metabolic acidosis, testosterone deficiency, bradycardia, pancytopenia, subcutaneous emphysema and pneumothorax [1,10,11]. Bratman also presents numerous mental health-related consequences. Additionally, he writes about food as a religion, where choosing food products and food intake can be performed at a spiritual level and the deviation from an ideal diet may be accompanied by a feeling of failure [1].

Orthorexia does not have an official definition, it has not been included in the current International Statistical Classification of Diseases and Related Health Problems or the Diagnostic and Statistical Manual of Mental Disorders (ICD-10, DSM-5), and the diagnostic criteria cited in the subject's literature are still only a proposal [5]. Many questions arise as to the relationship between $\mathrm{ON}$ and other nosological units. In the subject's literature, ON is sometimes presented as an eating disorder (ED), sometimes as an obsessive-compulsive disorder (OCD) [13-15]. Scientists also suggest that the American Psychological Association (APA) should modify the eating disorder not otherwise specified (EDNOS) category and define new types of eating disorders [16]. There is also disagreement among researchers as to whether ON should be considered a separate disorder, a variant of a currently recognized disorder (simply) a disturbed eating behavior or a disorder at all $[17,18]$. Nevertheless, the National Eating Disorders Association (NEDA) has published official information on ON, emphasizing the need for further research in this area [19].

The available literature provides ambiguous empirical data regarding the prevalence of ON. It varies between countries and between different social groups within a given country. Research to date indicates that the tendency towards orthorectic behaviors in the general population ranges from $1 \%$ [20] to $75.2 \%$ [21]. On the other hand, research conducted among youth and students indicates ON prevalence ranging from $2.5 \%$ among German students [22] to over $88 \%$ among Brazilian dietitian students [23]. Among Polish students, the incidence of $\mathrm{ON}$ ranges from $52.6 \%$ [24] to $76.7 \%$ [25] using the original version of the ORTO-15 questionnaire and a threshold of 40 points. However, after lowering the threshold to 35 , the incidence of orthorectic behavior decreased and ranged from $13.7 \%[24,26]$ to $28.3 \%$ [27,28]. The risk of the occurrence of orthorectic disorders measured by the Polish version of the ORTO-15 questionnaire reached 65.1\% [29].

The aim of this study was to assess the prevalence of orthorectic behaviors in young people and to assess their attitudes towards caring for their health.

The following research variables were distinguished within the research model:

1. Orthorexia - a variable describing the level of the respondents' obsessive thoughts about the quality of consumed foods, selective eating of chosen products and methods of preparing meals. To measure this variable, the ORTO-15 questionnaire was used.

2. Self-assessment of the presence of eating-related problems-a variable describing the respondents' individual attitudes towards food. To measure this variable, the EAT-26 questionnaire was used. This variable is complex in nature and has three components: dieting, bulimia and food preoccupation, and oral control.

3. Concern for health-a variable describing the interest in one's own health and the health value of food. Here, to measure this variable, the Health Concern Scale was used. 


\section{Material and Methods}

\subsection{The Following Study Was Conducted between January and April 2019 by a Licensed Psychologist}

The research was carried out among young people (pupils, students, employees and students who were also employed) aged 16-35 $(n=538)$ inhabiting the Lubelskie Voivodeship. The study was conducted in 3 secondary schools ( 2 high schools, 1 technical high school; 5 grades altogether) and 3 universities (Medical University of Lublin, Catholic University of Lublin, the University of Economics and Innovation in Lublin). Schools and universities were selected at random, after taking into account all entities located in the Lubelskie Voivodeship. Afterwards, at each school, classes and groups of students were also randomly selected. To ensure a high return of completed questionnaires, the researchers selected classes and groups of students that could be reached directly (during classes). Teachers and other staff members aged up to 35 and present on the day of the study were also asked to participate. In total, the questionnaire was distributed to 600 respondents; however, only 538 of them returned it, setting the participation rate at $89.7 \%$. After initial verification, 473 complete and correctly filled out questionnaires were qualified for further analysis.

Persons under 16 years of age were excluded from the study $(n=7)$ due to the insufficient impact on dietary choices [4]. The reason that we concentrated on late adolescence (16-18 year) and early adulthood (18-35 year) is because the risk of orthorectic disorders, as was indicated by numerous authors $[4,16,30,31]$, most frequently occurs both in young and slightly older people. Additionally, from a psychological point of view, this period may prove crucial because young adults are becoming more independent from their parents and beginning to make their own food choices. People who obtained a positive result in the Eating Attitudes Test (EAT-26) (i.e., 20 points or more; $n=47$ ) were also excluded from further analyses, because they are at risk of developing eating disorders, and this could have altered the study's results.

This criterion was also applied in other Polish studies [29]. Thanks to this, the authors could elicit respondents whose eating behavior was not disturbed. Questionnaires that were considered non-diagnostic $(n=11)$ were also excluded from further analysis (e.g., those incomplete or filled out in an unreliable manner).

\subsection{The Study Was Conducted Using the Following Research Tools}

The only tool for determining the risk of orthorexic disorders at the time of the study was the Bratman test, which is not a diagnostic tool; the EHQ questionnaire, which, at that time, lacked a Polish language version; and the ORTO-15 questionnaire in the Polish language version.

\subsubsection{Questionnaire ORTO-15}

The ORTO-15 questionnaire [3] consists of 15 items describing the severity of orthorectic behaviors. It includes cognitive, emotional and clinical aspects of orthorectic disorders. Respondents provide answers using a 4-point Likert scale-always, often, sometimes, never-to which point values from 1 to 4 are assigned. The authors determined a threshold value of 40 points. A lower score indicates a tendency towards orthorectic disorders.

The ORTO-15 questionnaire was adapted to Polish conditions by Brytek-Matera et al. [29]. As a result of analyses, the authors received a 9-item tool, whose Cronbach's alpha value was 0.644 . The obtained result indicates acceptable reliability but does not meet the Nunnally criterion (acceptable level of reliability threshold $\alpha>0.70$ ) [32]. In connection with the above, it was decided to re-check the reliability of the tool in question and, on the basis of the obtained results, remove certain items.

Because the calculated Cronbach alpha reliability coefficient for the original 15-item version of the ORTO-15 questionnaire was 0.259 , and 0.651 for the Polish version, a decision was made to remove items from the questionnaire that were the least correlated with the overall result. Finally, a 6-item tool (items 4, 6, 10, 11, 12, 14) was obtained (ORTO-6), where the reliability increased to 0.696 . This is a satisfactory result and close to the acceptable 
value of 0.7 required for scientific research [33]. In this way, the ORTO-6 questionnaire was created, which included 4 ranges (lowest possible score of 6 points).

- 6-7 points-orthorectic disorders;

- 8-11points-tendency towards orthorexy;

- $\quad 12-15$ points-appropriate eating habits;

- 16-24 points-low food interest.

Recently, a new 6-item (item 3, 4, 7, 10, 11, 12) modification of the ORTO-15 questionnaire became available, called ORTO-R [34].

The study used the authors' own modification of the ORTO-15 questionnaire, the ORTO-6, which comprises the following questions:

Are your eating choices conditioned by your worry about your health status?

Are you willing to spend more money to have healthier food?

Do you think that the conviction to eat only healthy food increases self-esteem?

Do you think that eating healthy food changes your lifestyle (frequency of eating out, friends, ... )?

Do you think that consuming healthy food may improve your appearance?

Do you think that on the market there is also unhealthy food?

\subsubsection{Eating Attitudes Test-26 (EAT-26)}

EAT-26 is a self-assessment test, most often used as a screening tool to detect eating disorder symptoms in the general population. It consists of 26 items and 3 subscales: dieting, bulimia and food preoccupation and oral control. Respondents provide answers on a 6-point scale, from "always" to "never". The maximum number of points for each item is " 3 ", which is synonymous with the strongest test feature expressed. The final result is the sum of all subscales. A score equal to or above 20 points suggests the risk of disturbances in the fulfillment of food needs and attitudes towards one's own body. Alpha Cronbach's reliability for the entire scale is 0.84 [35].

\subsubsection{Health Concern Scale (HCS)}

HCS [36] consists of 10 statements describing interest in health and the relationship of excessive consumption of certain food products, e.g., sugar, fat, salt or food additives, with certain diseases, e.g., hypertension and ischemic heart disease. Test subjects have a 7-point response scale, ranging from "definitely not" (1 point) to "definitely yes" (7 points). The item which contained negation (9) was recoded. The results were calculated for the entire HCS scale. The more points a respondent received, the greater were his/her health concerns. Based on the sum of points from the HCS scale, people with negative, neutral or positive health attitudes were distinguished. As the division criterion, the authors established $1 / 3$ and $2 / 3$ of the points range (negative attitude-10-29, neutral attitude 30-50 and positive attitude $51-70$ points).

Obtained results were subjected to statistical analysis using the IBM SPSS Statistics version 23. For analysis, the authors applied the ANOVA test, Tukeya test and Cronbach's alpha.

\section{Results}

\subsection{Division of the Study Group Based on the ORTO-6 Questionnaire}

The study group was divided based on statistical and empirical criteria. According to the statistical criterion established by Kelley [37], the division of the research group was based on extremes (in order to assess the differences between them) so that at each of the extremities of the distribution of results (so-called "tails") was $25-27 \%$ of the total number of cases. In such a situation, the power level of performed tests is the highest. An additional empirical criterion determined after the authors of the Polish validation of the ORTO-15 questionnaire [24], which referred to the clinical picture, was also added. According to the authors, the best correlations in recognizing the risk of orthorectic disorders and the 
risk of eating disorders are obtained when the cut-off threshold is set at 35 points. This leads to the separation of a group of people with orthorectic disorders consisting of $5 \%$ of the respondents. Accordingly, in the first extreme group-“"tendency to orthorectic disorders" - an additional empirical criterion of 5\% was used, thanks to which the "with the dominance of the orthorectic symptoms" group was distinguished.

Applying the above criteria, four subgroups were identified among the respondents: those with the dominance of orthorectic symptoms $(3.6 \%)$, people with a tendency towards orthorectic disorders $(29.2 \%)$, people who eat properly $(44.4 \%)$ and those with low food interest $(22.8 \%)$.

The vast majority of the respondents were female $(70 \%)$. The majority of the respondents, both male and female, had proper eating habits ( $47.4 \%$ and $37.3 \%$, respectively). The dominance of orthorectic symptoms was twice as likely to appear among women (4.2\%) than among men $(2.1 \%)$. It is worth mentioning that the tendency towards orthorectic disorders does not exhibit such differences between women (30.5\%) and men (26.1\%). What is interesting is that the occurrence of low food interest is 1.93 times higher than among women. Detailed data are presented in Table 1.

Table 1. Division of the research group into four categories based on the ORTO-6 questionnaire.

\begin{tabular}{|c|c|c|c|c|c|c|c|}
\hline \multirow{3}{*}{ Categories } & \multicolumn{6}{|c|}{ Sex } & \multirow{3}{*}{$\begin{array}{c}\text { OR } \\
\text { (Women/Men) }\end{array}$} \\
\hline & \multicolumn{2}{|c|}{ Women } & \multicolumn{2}{|c|}{ Men } & \multicolumn{2}{|c|}{ All } & \\
\hline & $n$ & $\%$ & $n$ & $\%$ & $n$ & $\%$ & \\
\hline Orthorectic symptoms as dominant & 14 & 4.2 & 3 & 2.1 & 17 & 3.6 & 2.00 \\
\hline Tendency towards orthorectic disorders & 101 & 30.5 & 37 & 26.1 & 138 & 29.2 & 1.17 \\
\hline Proper eating habits & 157 & 47.4 & 53 & 37.3 & 210 & 44.4 & 1.27 \\
\hline Low food interest & 59 & 17.8 & 49 & 34.5 & 108 & 22.8 & $1.93 *$ \\
\hline All & 331 & 70 & 142 & 30 & 473 & 100 & - \\
\hline
\end{tabular}

n-number; ${ }^{*}$-Signifies the odd ratio Men/Women.

\subsection{Dietary Restrictions}

Most frequently, respondents limited the general amount of the consumed food $(67.2 \%)$, sugar and sweets $(65.3 \%)$, food containing high amounts of fat $(60 \%)$ and fat $(57.7 \%)$. Far fewer respondents indicated other products.

Afterwards, a statistical analysis was performed to determine the relationship between people showing orthorectic tendencies and dietary restrictions.

The Chi-2 test showed a statistically significant correlation between the group in which orthorectic symptoms are dominant and limiting foods with significant amounts of fat $($ Chi-2 $=56.331 ; p=0.000)$, fats $($ Chi-2 $=33.465 ; p=0.000)$, sugar and sweets $($ Chi-2 $=35.311$; $p=0.000)$, meat and sausages (Chi-2 $=15.118 ; p=0.002)$ and the total amount of food consumed (Chi-2 $=8.255 ; p=0.041)$. This indicates that there are statistically significant differences between those at risk of orthorectic disorders and dietary restrictions. In the case of other dietary products, results proved statistically insignificant.

Detailed data are presented in Table 2.

Foods containing high amounts of fat and general fat consumption are significantly more limited by people with orthorexia than by other respondents $(88.2 \%$ and $82.4 \%$, respectively). Similarly, regarding the consumption of sugar and sweets, those with orthorexia (82.4\%) and a tendency towards orthorexia (81.9\%) tended to limit sweets more compared to other study participants. Analogous to this, albeit to a lesser extent, is the situation pertaining to meat and sausage consumption. A statistically significant correlation was observed between respondents in whom orthorectic symptoms were dominant and limiting the total amount of food consumed-limiting total food intake was observed more frequently among respondents with a tendency $(74.6 \%)$ towards orthorexia than those not focused on food (57.4\%). Detailed data are presented in Table 3. 
Table 2. Restrictions in consuming specific food products among all of the respondents, based on the ORTO-6 questionnaire.

\begin{tabular}{ccccc}
\hline I Limit: & \multicolumn{2}{c}{ All } & \multicolumn{2}{c}{ Orthorectic Symptoms as Dominant } \\
\cline { 2 - 5 } & $\boldsymbol{n}$ & $\mathbf{\%}$ & Chi-2 & $p$ \\
\hline Amount of food & 318 & 67.2 & 8.255 & 0.041 \\
Food containing large amounts of fats & 284 & 60.0 & 56.331 & 0.000 \\
Fats & 273 & 57.7 & 33.465 & 0.000 \\
Sugar, Sweets & 309 & 65.3 & 35.311 & 0.000 \\
Grain products & 90 & 19.0 & 7.789 & 0.051 \\
Fish & 53 & 11.2 & 3.214 & 0.360 \\
Meat, sausage & 109 & 23.0 & 15.118 & 0.002 \\
Raw vegetables & 41 & 8.7 & 1.940 & 0.585 \\
Raw fruits & 19 & 4.0 & 5.428 & 0.143 \\
Dairy products & 101 & 21.4 & 3.680 & 0.298 \\
\hline
\end{tabular}

$\%$ do not add up to 100, because respondents could choose more than one answer; $n$-number; Chi-2—test; $p$-statistical significance.

Table 3. Restrictions of specific products in specified groups based on the ORTO-6 questionnaire.

\begin{tabular}{ccccccccc}
\hline \multirow{2}{*}{ I Limit: } & $\begin{array}{c}\text { Orthorectic Symptoms as } \\
\text { Dominant }\end{array}$ & $\begin{array}{c}\text { Tendency towards } \\
\text { Orthorexia }\end{array}$ & \multicolumn{2}{c}{ Healthy Eating } & Low Food Interest \\
\cline { 2 - 9 } & $\boldsymbol{n}$ & $\mathbf{\%}$ & $\boldsymbol{n}$ & $\mathbf{\%}$ & $\boldsymbol{n}$ & $\mathbf{\%}$ & $\boldsymbol{n}$ & $\mathbf{\%}$ \\
\hline Amount of food & 12 & 70.6 & 103 & 74.6 & 141 & 67.1 & 62 & 57.4 \\
Products high in fats & 15 & 88.2 & 104 & 75.4 & 131 & 62.4 & 34 & 31.5 \\
Fats & 14 & 82.4 & 94 & 68.1 & 127 & 60.5 & 38 & 35.2 \\
Sugar, Sweets & 14 & 82.4 & 113 & 81.9 & 131 & 62.4 & 51 & 47.2 \\
Grain products & 3 & 17.6 & 37 & 26.8 & 34 & 16.2 & 16 & 14.8 \\
Fish & 0 & 0.0 & 13 & 9.4 & 26 & 12.4 & 14 & 13.0 \\
Meat, sausages & 7 & 41.2 & 44 & 31.9 & 43 & 20.5 & 15 & 13.9 \\
Raw vegetables & 0 & 0.0 & 11 & 8.0 & 20 & 9.5 & 10 & 9.3 \\
Raw fruit & 0 & 0.0 & 6 & 4.3 & 5 & 2.4 & 8 & 7.4 \\
Dairy products & 5 & 29.4 & 36 & 26.1 & 40 & 19.0 & 20 \\
\hline
\end{tabular}

$\%$ do not add up to 100 , because respondents could choose more than one answer; $n-$ number.

\subsection{Caring for Health}

The overall score for caring for health was calculated using the Health Concern Scale (HCS). The respondents achieved results in the range of 10 to 70 . The average result was 45 ( $\mathrm{SD}=12.01)$. The higher the average value presented by the HCS, the more positive attitudes are presented by the respondents. Obtained data indicate that respondents mostly have neutral attitudes towards caring for their health. Detailed data are presented in Table 4.

Table 4. Caring for health among all respondents.

\begin{tabular}{|c|c|c|c|c|c|c|c|c|c|}
\hline \multirow{4}{*}{$\begin{array}{l}\text { Health Concern } \\
\text { (HCS) }\end{array}$} & \multicolumn{8}{|c|}{ ORTO 6} & \multirow{3}{*}{$\begin{array}{c}\text { ANOVA } \\
\text { F, } p \text {, R.I. } \\
\text { (Tukey Test) }\end{array}$} \\
\hline & \multicolumn{2}{|c|}{$\begin{array}{c}\text { Orthorectic Symptoms } \\
\text { as Dominant }\end{array}$} & \multicolumn{2}{|c|}{$\begin{array}{l}\text { Tendency towards } \\
\text { Orthorexia }\end{array}$} & \multicolumn{2}{|c|}{$\begin{array}{c}\text { Healthy } \\
\text { Eating }\end{array}$} & \multicolumn{2}{|c|}{$\begin{array}{l}\text { Low Food } \\
\text { Focus }\end{array}$} & \\
\hline & $\mathbf{M}$ & SD & $\mathbf{M}$ & SD & $\mathbf{M}$ & SD & $\mathbf{M}$ & SD & \\
\hline & 47.65 & 12.23 & 47.89 & 11.69 & 44.01 & 11.73 & 43.93 & 12.34 & $\begin{array}{c}3.248 \\
0.022 \\
2 / 4\end{array}$ \\
\hline
\end{tabular}

$\mathrm{M} —$ average; SD—standard deviation; $p$ —statistical significance.

Variance analysis revealed that respondents with a tendency towards orthorexia obtained significantly higher scores on the HCS scale than people with low food interest. No statistically significant, linear correlation was observed between the overall result for ORTO and the Health Concern Scale $(\mathrm{R}=0.084 ; p=0.068)$. 


\section{Discussion}

Orthorectic disorders are attracting more and more interest among representatives of various disciplines. Despite ongoing research and the increasing number of publications, it still remains a relatively poorly understood disorder. This is partly due to research conducted on non-clinical trials, a relatively small number of case studies $[2,11,38,39]$ and also due the lack of a reliable diagnostic tool.

Despite the fact that the ORTO-15 questionnaire has recently met with criticism [40], a literature review proves that it is the most frequently applied tool to assess ON. Moreover, it should be noted that the lack of Polish language versions of other available methods (the use of the Bratman Test for scientific research is not recommended by the authors themselves, and the Polish version of the Eating Habits Questionnaire (EHQ) [41] did not exist at the time of conducting this study) left no choice and there was limited research on the use of the ORTO- 15 tool. It can be assumed that other researchers also encounter similar problems.

The prevalence rate of orthorectic disorders among young people ranges from $2.5 \%$ among German students [22] to over 88\% among Brazilian dietitian students [23] compared to the incidence of traditional eating disorders, whose prevalence is estimated at $0.4 \%$ for mental anorexia and 1-1.5\% for bulimia nervosa (by the American Psychiatric Association in 2013), seems very high. However, our own research revealed that the incidence of orthorectic disorders is estimated at $3.6 \%$, which indicates that it is not common. Similar results can be observed in studies conducted by other authors.

In the group of German students, the prevalence of orthorectic behavior ranges from $2.5 \%$ [22] to 3.3\% [42]. Similar results were also reported by Oberle et al. [43] and Chard et al. [44] among American students ( $4.5 \%$ and $8 \%$, respectively), and among Chinese students by He et al. [45]. However, due to the use of different measurement tools or different versions of the ORTO-15 questionnaire and, thus, different cut-off points, caution should be exercised in drawing conclusions from comparative analysis. Moreover, reported discrepancies may also result from cultural differences between research participants $[16,46]$ as well as the heterogeneity of selected study groups (e.g., in resident doctors, the prevalence of $\mathrm{ON}$ is $45.5 \%$ [47], Ashtanga yoga practitioners- $86 \%$ [48], Registered Dietitian Nutritionists (RDNs) - 49.5\% [49], general population-75.2\% [21], students-75\% [27]).

The problem with estimating the occurrence of orthorectic behaviors may be not only the use of an excessively high cut-off threshold in the ORTO-15 questionnaire, but also the fact that only two basic groups are distinguished on the basis of the obtained result, i.e., those exhibiting $\mathrm{ON}$ behaviors and those not showing the features of this disorder. Consequently, this translates into a high prevalence rate of $\mathrm{ON}$ in the study groups.

Therefore, the authors of this study decided to distinguish four groups based on the result obtained using the ORTO-6 questionnaire, i.e., orthorectic disorders, tendency towards orthorexia, proper nutrition and low food interest. This approach allows us not only to significantly reduce the level of prevalence of this disorder, but also to distinguish an increased risk group (i.e., tendency for orthorexia), to which preventive measures can be applied.

Additionally, this approach is also consistent with the latest position of Bratman [50], who distinguished two stages of ON, the so-called "healthy orthorexia", when an individual is interested in healthy eating but does not show pathological features (which, in our own research, corresponds to the category "orthorexia tendency") and "orthorexia nervosa", when the individual is obsessed with pursuing a healthy diet (which corresponds to the "orthorexia" category). This solution was also used by F. Barthels, F. Meyer and R. Pietrowsky [51] in the Düsseldorf Orthorexia Scale (DOS). As a result, the prevalence rate of ON measured by the DOS scale ranges from 2.5\% [22] to 10.5\% [52]. Moreover, the early introduction of adequate measures among people with $\mathrm{ON}$ tendencies is especially important because orthorectic disorders may cause numerous negative physical and psychosocial consequences. 
The authors' modification of the ORTO-15, the ORTO-6 questionnaire, may help to solve current problems with measuring the level of orthorectic disorders.

According to our own research, orthorectic disorders occur more often among women than among men $(4.2 \%, 2.1 \%$, respectively), which is also confirmed in the research of other authors [53-56]. It should be noted, however, that men in previous orthorectic disorder studies usually comprised a smaller group. Therefore, these results may be less reliable for assessing gender differences.

The analysis of applied restrictions in food consumption carried out in this study allowed us to observe significant differences between distinguished groups in the type of limited/restricted food products. The most limited food products included products high in fats, sugar and sweets, meat and sausages and the total amount of food consumed. These products were definitely more often restricted by people with orthorectic disorders and/or a tendency towards orthorexia. Restrictions of meat and meat product consumption are confirmed by a relatively high content of substances that have an adverse effect on health, such as salts, additives, saturated fatty acids and fats, which are a source of cholesterol. High consumption of animal fat is one of the main causes of cardiovascular diseases, diabetes and obesity; therefore, its consumption during the day should be as low as possible [57]. Specialists from the International Agency for Research on Cancer (IARC) [58] also emphasize that greater than recommended meat consumption and the consumption of processed meat products can contribute to some cancers. According to the Polish Public Opinion Center (CBOS) report from [59], 34\% of Poles limit the consumption of fatty foods, and $12 \%$ of meat. These results are similar to the results obtained in our own research in the non-food focus group ( $31.5 \%$ and $13.9 \%$ for fatty foods and meat, respectively). Similarly, a diet high in sugars, especially simple ones, can cause many adverse health effects. Excessive sugar and sweets consumption, due to the high calorific value, and often also the presence of fat, may cause overweight and obesity and contribute to the development of caries, type 2 diabetes and atherosclerosis [57]. A survey conducted by CBOS [59] revealed that $55 \%$ of Poles limit their sugar and sweets consumption. This result is similar to the results obtained in this research by people with proper eating habits (62.4\%) and those non-food-focused $(47.2 \%)$. Recommendations on limiting the consumption of meat, animal fats as well as sugar and sweets have been included among the principles of healthy nutrition developed by the Institute of Food and Nutrition (IŻŻ) experts [57]. The literature emphasizes that the diet of an average Pole deviates from recommendations on proper nutrition in the area of excessive consumption of the abovementioned products [60]. Therefore, nutritional restrictions undertaken by people with orthorexia and a tendency towards orthorexia should be considered desirable and beneficial to health as it could be assumed that they were undertaken not only because of taste preferences, however, but above all because of greater nutritional awareness. At the same time, it should be underlined, however, that excessive concentration on healthy eating can lead to the elimination of entire food groups from the diet, which in turn may have negative health consequences [61]. The subject's literature presents various case reports of orthorexia, e.g., a case of 28-year-old who initially eliminated fats from her diet and then limited the consumption of other products [2], a 30-year-old man who limited his diet to brown rice and fresh vegetables only [11] and a 33-year-old woman whose diet consisted only of fresh fruit, vegetables and eggs [39]. In all the cases cited, extreme nutritional restrictions resulted in serious health consequences requiring medical intervention. Moreover, it should be emphasized that the desire to eat healthy food is not a disorder in itself, but excessive concentration on the quality of consumed products and the method of preparing meals, combined with the existence of negative consequences of such consumption, may lead to ON.

The definition of ON emphasizes that the obsession with healthy eating results from excessive health concerns [1], which have not yet been studied but determined only on the basis of patients' observations. The results of our own research did not confirm this theory. Although people with a tendency towards orthorexia and people with orthorectic disorders showed a higher level of care for their health, and the results obtained by them 
indicate a tendency to maintain a positive attitude, they nevertheless fall within the range of neutral attitudes, similarly to people who eat properly and those not food-focused. No significant differences between orthorectic disorders and caring for health among young people aged 18-35 are visible in the study by Plichta and Jeżewska-Zychowicz either [27] The result obtained by the authors of this study was surprising; however, after careful analysis of the used tools, it may have a logical justification. The Health Concern Scale expresses fears related to the impact of diet and, more precisely, the excessive consumption of substances such as sugar or fat on health. Thus, since people with orthorexia significantly reduced their intake, they also minimized their adverse effects on health. Therefore, the result regarding people with orthorectic disorders within neutral health attitudes may be justified.

Additionally, current research conducted among various groups indicates that health concerns increase with age and are most visible among the elderly and the sick $[62,63]$. Neutral attitudes towards health in the studied group may additionally be associated with the young age of respondents and lack of complaints related to improper nutrition; nevertheless, they are consistent with the results obtained by other authors who also focused on young respondents $[64,65]$.

\section{Research Limitations}

The first encountered limitation is the availability of literature pertaining to health care and eating behaviors in orthorectic disorders [16,27]. Additionally, the conducted research also has its limitations, such as the inability to consider the research group as representative as their majority of respondents were female. Moreover, the validity of the ORTHO-15 questionnaire used to determine orthorectic disorders was recently questioned due to, among others, variable internal consistency (Cronbach's alpha from 0.14 to 0.82; Cronbach's alpha mean 0.55), contradictory credibility and doubts about the cut-off point [65-68]. Nevertheless, as noted earlier, it was the only tool available at the time of the research. Finally, the study had a cross-sectional design; therefore, it was impossible to draw conclusions as to the direction of the impact of the studied variables.

\section{Conclusions}

Conducted research revealed that the prevalence of orthorectic disorders in the studied group of young people is a relatively rare phenomenon, although a large number of respondents have a tendency towards this disorder. In addition, people with orthorectic disorders and a tendency towards orthorexia present neutral (with a tendency to positive) attitudes towards caring for their health. The obtained results may be the basis for further research on ON symptoms and may be helpful in understanding the specificity of this disorder.

It would be desirable to repeat the current studies in the future on a more representative group, using more reliable tools for orthorectic disorder assessment to verify the obtained results.

In addition, the nutritional behaviors observed in the studied group show some irregularities, which indicates the need for preventive and educational activities among young people aimed at increasing awareness of the role of proper nutrition.

Certainly, the greatest challenge for future research is the correct assessment of ON, which is undoubtedly difficult, because many of the behaviors characteristic of this disorder fall within the categories of normality and sometimes may even be laudable. The problem with precise diagnosis of this disorder may also result from distinguishing, on the basis of obtained results, only two groups, i.e., people exhibiting $\mathrm{ON}$ behaviors and those not exhibiting features of the disorder. Therefore, one of the major areas of future research would be to create a reliable diagnostic tool and to finally distinguish between orthorexia and overdiagnosis. 
Author Contributions: Conceptualization, N.K.-W.; methodology, N.K.-W. and A.N.; validation, N.K.-W. and A.N.; formal analysis, N.K.-W. and A.N.; investigation, N.K.-W. and A.N.; data curation, N.K.-W.; writing—original draft preparation, N.K.-W., R.P., A.Z. and M.D.; writing-review and editing, R.P., A.Z. and M.D.; visualization, A.Z. and M.D.; supervision, M.D. and A.N.; project administration, R.P. All authors have read and agreed to the published version of the manuscript.

Funding: This research was funded by a project for young researchers of the Medical University of Lublin, project number MNmb630.

Institutional Review Board Statement: The study was conducted according to the guidelines of the Declaration of Helsinki and approved by the Bioethics Committee at the Medical University of Lublin (KE 0254/234/2016).

Informed Consent Statement: Informed consent was obtained from all subjects involved in the study.

Data Availability Statement: The data presented in this study are available from Natalia KaźmierczakWojtaś.

Conflicts of Interest: The authors declare no conflict of interest.

\section{References}

1. Bratman, S.; Knight, D. Health food Junkies. Orthorexia Nervosa: Overcoming the Obsession with Healthful Eating; Broadway Books: New York, NY, USA, 2000.

2. Catalina Zamora, M.L.; Bote Bonaechea, B.; García Sánchez, F.; Ríos Rial, B. Orthorexia nervosa. A new eating behavior disorder? Actas Esp. Psiquiatr. 2005, 33, 66-68.

3. Donini, L.M.; Marsili, D.; Graziani, M.P.; Imbriale, M.; Cannella, C. Orthorexia nervosa: A preliminary study with a proposal for diagnosis and an attempt to measure the dimension of the phenomenon. Eat. Weight Disord. 2004, 9, 151-157. [CrossRef]

4. Donini, L.M.; Marsili, D.; Graziani, M.P.; Imbriale, M.; Cannella, C. Orthorexia nervosa: Validation of a diagnosis questionnaire. Eat. Weight Disord. 2005, 10, 28-32. [CrossRef]

5. Dunn, T.M.; Bratman, S. On orthorexia nervosa: A review of the literature and proposed diagnostic criteria. Eat. Behav. 2016, 21, 11-17. [CrossRef]

6. Korinth, A.; Schiess, S. Westenhoefer, J. Eating behaviour and eating disorders in students of nutrition sciences. Public Health Nutr. 2010, 13, 32-37. [CrossRef]

7. Vandereycken, W. Media hype, diagnostic fad or genuine disorder? Professionals' opinions about night eating syndrome, orthorexia, muscle dysmorphia, and emetophobia. Eat. Disord. 2011, 19, 145-155. [CrossRef] [PubMed]

8. Brytek-Matera, A. Orthorexia nervosa-an eating disorder, obsessive-compulsive disorder or disturbed eating habit? Arch. Psychiatry Psychother. 2012, 14, 55-60.

9. Alvarenga, M.S.; Martins, M.C.T.; Sato, K.S.C.J.; Vargas, S.V.A.; Philippi, S.T.; Scagliusi, F.B. Orthorexia nervosa behavior in a sample of Brazilian dietitians assessed by the Portuguese version of ORTO-15. Eat. Weight Disord. 2012, 17, 29-35. [CrossRef]

10. Moroze, R.M.; Dunn, T.M.; Craig Holland, J.; Yager, J.; Weintraub, P. Microthinking about micronutrients: A case of transition from obsessions about healthy eating to near-fatal "orthorexia nervosa" and proposed diagnostic criteria. Psychosomatics 2015, 56, 397-403. [CrossRef] [PubMed]

11. Park, S.W.; Kim, J.Y.; Go, G.J.; Jeon, E.S.; Pyo, H.J.; Kwon, Y.J. Orthorexia nervosa with hyponatremia, subcutaneous emphysema, pneumomediastimum, pneumothorax, and pancytopenia. Electrolytes Blood Press. 2011, 9, 32-37. [CrossRef] [PubMed]

12. Nevin, S.M.; Vartanian, L.R. The stigma of clean dieting and orthorexia nervosa. J. Eat. Disord. 2017, 5, 37. [CrossRef] [PubMed]

13. Hadjistavropoulos, H.; Lawrence, B. Does anxiety about health influence eating patterns and shape-related body checking among females? Pers. Indiv. Differ. 2007, 43, 319-328. [CrossRef]

14. Kinzl, J.F.; Hauer, K.; Traweger, C.; Kiefer, I. Orthorexia nervosa in dieticians. Psychother. Psychosom. 2006, 75, 395-396. [CrossRef]

15. Koven, N.S.; Abry, A.W. The clinical basis of orthorexia nervosa: Emerging perspectives. Neuropsychiatr. Dis. Treat. 2015, 8 , 385-394. [CrossRef] [PubMed]

16. Varga, M.; Thege, B.K.; Dukay-Szabó, S.; Tury, F.; van Furth, E.F. When eating healthy is not healthy: Orthorexia nervosa and its measurement with the ORTO-15 in Hungary. BMC Psychiatry 2014, 14, 59. [CrossRef]

17. Kummer, A.; Dias, F.M.; Teixeira, A.L. On the concept of orthorexia nervosa. Scand. J. Med. Sci. Sports 2008, 18, 395-396. [CrossRef]

18. Meule, A.; Voderholzer, U. Orthorexia nervosa-it is time to think about abandoning the concept of a distinct diagnosis. Front. Psychiatry 2021, 12, 640401. [CrossRef]

19. Janas-Kozik, M.; Zejda, J.; Stochel, M.; Brozek, G.; Janas, A.; Jelonek, I. Ortoreksja-nowe rozpoznanie? Psychiatr. Pol. 2012, 46, 441-450. [PubMed]

20. Dunn, T.M.; Gibbs, J.; Whitney, N.; Starosta, A. Prevalence of orthorexia nervosa is less than 1\%: Data from a US sample. Eat. Weight 2017, 22, 185-192. [CrossRef]

21. Haddad, C.; Obeid, S.; Akel, M.; Honein, K.; Akiki, M.; Azar, J.; Hallit, S. Correlates of orthorexia nervosa among a representative sample of the Lebanese population. Eat. Weight Disord. 2019, 24, 481-493. [CrossRef] 
22. Rudolph, S.; Göring, A.; Jetzke, M.; Großarth, D.; Rudolph, H. The prevalence of orthorectic eating behavior of student athletes. Dtsch. Z. Sportmed. 2017, 68, 10-13. [CrossRef]

23. de Souza, Q.J.O.; Rodrigues, A.M. Risk behavior for orthorexia nervosa in nutrition students. J. Bras. Psiquiatr. 2014, 63, $200-204$.

24. Stochel, M.; Janas-Kozik, M.; Zejda, J.; Hyrnik, J.; Jelonek, I.; Siwiec, A. Validation of ORTO-15 Questionnaire in the group of urban youth aged 15-21. Psychiatr. Pol. 2015, 49, 119-134. [CrossRef]

25. Łucka, I.; Janikowska-Hołoweńko, D.; Domarecki, P.; Plenikowska-Ślusarz, T.; Domarecka, M. Orthorexia nervosa-a separate clinical entity, a part of eating disorder spectrum or another manifestation of obsessive-compulsive disorder? Psychiatr. Pol. 2019, 53, 371-382. [CrossRef] [PubMed]

26. Hyrnik, J.; Janas-Kozik, M.; Stochel, M.; Jelonek, I.; Siwiec, A.K.; Rybakowski, J. The assessment of orthorexia nervosa among 1899 Polish adolescents using the ORTO-15 questionnaire. Int. J. Psychiatry Clin. Pract. 2016, 20, 199-203. [CrossRef] [PubMed]

27. Plichta, M.; Jeżewska-Zychowicz, M. Eating behaviors, attitudes toward health and eating, and symptoms of orthorexia nervosa among students. Appetite 2019, 137, 114-123. [CrossRef]

28. Plichta, M.; Jeżewska-Zychowicz, M. Orthorexic Tendency and Eating Disorders Symptoms in Polish Students: Examining Differences in Eating Behaviors. Nutrients 2020, 12, 218. [CrossRef] [PubMed]

29. Brytek-Matera, A.; Krupa, M.; Poggiogalle, E.; Donini, L.M. Adaptation of the ORTHO-15 test to Polish women and men. Eat. Weight Disord. 2014, 19, 69-76. [CrossRef]

30. Fidan, T.; Ertekin, V.; Isikay, S.; Kirpinar, I. Prevalence of orthorexia among medical students in Erzurum, Turkey. Compr. Psychiatry 2010, 51, 49-54. [CrossRef]

31. McInerney-Ernst, E.M. Orthorexia Nervosa: Real Construct or Newest Social Trend? Ph.D. Thesis, University of Missouri-Kansas City, Kansas City, MO, USA, 2011. Unpublished.

32. Nunnally, J.C.; Bernstein, I.H. Psychometric Theory, 3rd ed.; McGraw-Hill Book Company: New York, NY, USA, 1976 ; p. 245.

33. Cronbach, L.J. Współczynnik alfa a struktura wewnętrzna testów. In Trafność i Rzetelność Testów Psychologicznych; Brzeziński, J., Ed.; Wybór tekstów; Wydawnictwo GWP: Gdańsk, Polska, 2005; pp. 177-212.

34. Rogoza, R.; Donini, L.M. Introducing ORTO-R: A revision of ORTO-15. Eat. Weight Disord. 2020. [CrossRef]

35. Garner, D.M.; Olmsted, M.P.; Bohr, Y.; Garfinkel, P.E. The Eating Attitudes Test: Psychometric features and clinical correlates. Psychol. Med. 1982, 12, 871-878. [CrossRef]

36. Kähkönen, P.; Tuorila, H. Consumer responses to reduced and regular fat content in different products: Effects of gender, involvement and health concern. Food Qual. Prefer. 1999, 10, 83-91. [CrossRef]

37. Kelley, T.L. The selection of upper and lower groups for the validation of test Items. J. Educ. Psychol. 1939, 30, 17-24. [CrossRef]

38. Lopes, R.; Melo, R.; Dias Pereira, B. Orthorexia nervosa and comorbid depression successfully treated with mirtazapine: A case report. Eat. Weight Disord. 2018, 25, 218. [CrossRef]

39. Saddichha, S.; Babu, G.N.; Chandra, P. Orthorexia nervosa presenting as prodrome of schizophrenia. Schizophr. Res. 2012, 134, 110. [CrossRef]

40. Missbach, B.; Barthels, F. Orthorexia nervosa: Moving forward in the field. Eat. Weight Disord. 2017, 22, 1. [CrossRef]

41. Gleaves, D.H.; Graham, E.C.; Ambwani, S. Measuring “Orthorexia”: Development of the eating habits Questionnaire. Int. J. Educ. Psychol. Assess. 2013, 12,1-18.

42. Depa, J.; Schweizer, J.; Bekers, S.K.; Hilzendegen, C.; Stroebele-Benschop, N. Prevalence and predictors of orthorexia nervosa among German students using the 21-item-DOS. Eat. Weight Disord. 2017, 22, 193-199. [CrossRef]

43. Oberle, C.D.; De Nadai, A.S.; Madrid, A.L. Orthorexia Nervosa Inventory (ONI): Development and validation of a new measure of orthorexic symptomatology. Eat. Weight Disord. 2020. [CrossRef] [PubMed]

44. Chard, C.A.; Hilzendegen, C.; Barthels, F.; Stroebele-Benschop, N. Psychometric evaluation of the English version of the Düsseldorf Orthorexie Scale (DOS) and the prevalence of orthorexia nervosa among a U.S. student sample. Eat. Weight Disord. 2019, 24, 275-281. [CrossRef]

45. He, J.; Ma, H.; Barthels, F.; Fan, X. Psychometric properties of the Chinese version of the Düsseldorf Orthorexia Scale: Prevalence and demographic correlates of orthorexia nervosa among Chinese university students. Eat. Weight Disord. 2019, 24, 453-463. [CrossRef]

46. Malmborg, J.; Bremander, A.; Olsson, M.C.; Bergman, S. Health status, physical activity, and orthorexia nervosa: A comparison between exercise science students and business students. Appetite 2017, 109, 137-143. [CrossRef] [PubMed]

47. Bağci Bosi, T.A.; Çamur, D.; Güler, C. Prevalence of orthorexia nervosa in resident medical doctors in the faculty of medicine (Ankara, Turkey). Appetite 2007, 49, 661-666. [CrossRef] [PubMed]

48. Valera, J.H.; Ruiz, P.A.; Valdespino, B.R.; Visioli, F. Prevalence of orthorexia nervosa among ashtanga yoga practitioners: A pilot study. Eat. Weight Disord. 2014, 19, 469-472. [CrossRef] [PubMed]

49. Tremelling, K.; Sandon, L.; Vega, G.L.; McAdams, C.J. Orthorexia Nervosa and Eating Disorder Symptoms in Registered Dietitian Nutritionists in the United States. J. Acad. Nutr. Diet. 2017, 117, 1612-1617. [CrossRef]

50. Bratman, S. Orthorexia vs. theories of healthy eating. Eat. Weight Disord. 2017, 22, 381-385. [CrossRef]

51. Barthels, F.; Meyer, F.; Pietrowsky, R. Düesseldorf orthorexia scale-construction and evaluation of a questionnaire measuring orthorexic eating behavior. Z. Klin. Psychol. Psychother. 2015, 44, 97-105. [CrossRef] 
52. Parra-Fernández, M.L.; Onieva-Zafra, M.D.; Fernández-Martínez, E.; Abreu-Sánchez, A.; Fernández-Muñoz, J.J. Assessing the Prevalence of Orthorexia Nervosa in a Sample of University Students Using Two Different Self-Report Measures. Int. J. Environ. Res. Public Health 2019, 16, 2459. [CrossRef]

53. Dell'Osso, L.; Carpita, B.; Muti, D.; Cremone, I.M.; Massimetti, G.; Diadema, E.; Gesi, C.; Carmassi, C. Prevalence and characteristics of orthorexia nervosa in a sample of university students in Italy. Eat. Weight Disord. 2018, 23, 55-65. [CrossRef] [PubMed]

54. Keller, M.F.; Konradsen, H. Orthorexia in young fitness participants. Klin. Sygepleje 2013, 27, 63-71. [CrossRef]

55. Koven, N.S.; Senbonmatsu, R. A neuropsychological evaluation of orthorexia nervosa. Open J. Psychiatry 2013, 3, 214-222. [CrossRef]

56. Parra-Fernandez, M.L.; Rodríguez-Cano, T.; Onieva-Zafra, M.D.; Perez-Haro, M.J.; Casero-Alonso, V.; Munoz Camargo, J.C.; Notario-Pacheco, B. Adaptation and validation of the Spanish version of the ORTO-15 questionnaire for the diagnosis of orthorexia nervosa. PLoS ONE 2018, 13, e0190722. [CrossRef] [PubMed]

57. Jarosz, M.; Wolnicka, K.; Sajór, I.; Wierzejska, R. Zalecenia dotyczące żywienia i aktywności fizycznej. In Normy Żywienia Dla populacji Polski; Jarosz, M., Ed.; Instytut Żywności i Żywienia: Warszawa, Polska, 2017; pp. 261-287.

58. International Agency for Research on Cancer WHO. Consumption of Red Meat and Processed Meat; IARC Monogr. Eval. Carcinog. Risk. Hum. 114; IARC Working Group: Lyon, France, 2018.

59. Centrum Badania Opinii Społecznej; Diety Polaków: Warszawa, Polska, 2014; p. 113.

60. Kunachowicz, H.; Czarnowska-Misztal, E.; Turlejska, H. Zasady Żywienia Człowieka; Wydawnictwo WSIP: Warszawa, Polska, 2000.

61. Babicz-Zielińska, E.; Komorowska-Szczepańska, W.; Łegowska, A.; Pasalska-Niewęgłowska, K. Zaburzenia w odżywianiu wynikające z troski o zdrowie. Fam. Medal. Primary Care Rev. 2012, 14, 123-125.

62. Jeżewska-Zychowicz, M. Czynniki społeczne a żywność i żywienie. In Żywienie a Zdrowie Publiczne; Gawęcki, J., Roszkowski, W., Eds.; Wydawnictwo Naukowe PWN: Warszawa, Polska, 2009.

63. Trondsen, T.; Braaten, T.; Lund, E.; Eggen, A.E. Health and seafood consumption patterns among women aged45-69 years. A Norwegian seafood consumption study. Food Qual. Prefer. 2004, 15, 117-128. [CrossRef]

64. Czarnocińska, J.; Jeżewska-Zychowicz, M.; Babicz-Zielińska, E.; Kowalkowska, J.; Wądołowska, L. Postawy Względem Żyzwości Żywienia i Zdrowia a Zachowania Żywieniowe Dziewczat i Młodych Kobiet w Polsce; Wydawnictwo UWM: Olsztyn, Polska, 2013.

65. Roncero, M.; Barrada, J.R.; Perpiñá, C. Measuring orthorexia nervosa: Psychometric limitations of the ORTO-15. Span. J. Psychol. 2017, 20, e41. [CrossRef] [PubMed]

66. Hayatbini, N.; Oberle, C.D. Are orthorexia nervosa symptoms associated with cognitive inflexibility? Psychiatry Res. 2019, 271, 464-468. [CrossRef]

67. Missbach, B.; Hinterbuchinger, B.; Dreiseitl, V.; Zellhofer, S.; Kurz, C.; König, J. When Eating Right, Is Measured Wrong! A Validation and Critical Examination of the ORTO-15 Questionnaire in German. PLoS ONE 2015, 10, e0135772. [CrossRef] [PubMed]

68. Zickgraf, H.F.; Ellis, J.M.; Essayli, J.H. Disentangling orthorexia nervosa from healthy eating and other eating disorder symptoms: Relationships with clinical impairment, comorbidity, and self-reported food choices. Appetite 2019, 134, 40-49. [CrossRef] 